09-May-20

\title{
What's so special about Giardia ventral flagella? Interspecies cross-reacting monoclonal antibody against Pneumocystis jiroveci reacts with cilia and sparks
}

Ewert Linder

Swedish Institute for Infectious Disease Control, Solna, Sweden

10 Department of Microbiology, Tumor and Cell Biology (MTC), Karolinska Institutet, Solna, Sweden

Current Address: Laivurinkatu 9A9, 00150 Helsinki, Finland

15 Financial Disclosure

The author received no specific funding for this work 


$$
\text { E. Linder Moab 4B8 anti Pneumocystis jiroveci }
$$

20 A mouse monoclonal antibody (Moab 4B8) cross-reacting with cilia/flagella was obtained by immunization with Pneumocystis-infected human lung tissue. A key observation was that Moab 4B8 reacted with the ventral flagella of Giardia intestinalis, but not with the three other flagellar pairs of this protozoan. To further identify the 4B8 target, its distribution was studied by immunofluorescence staining of cells and tissues of various origin.

25 The target epitope recognized by Moab 4B8 was found to be associated with structures rich in microtubules; e.g. the mitotic spindle of cultured cells, ciliated airway epithelia, Sertoli cells of the testis and ependymal cells lining brain ventricles. The conserved nature of the 4B8 target was further shown by its presence in cilia of metazoan Schistosome larva and the green alga Chlamydomonas reinhardtii. Absence of the 4B8 target from Trypanosomes and

30 Leishmania flagella suggested that it is involved in some function not primarily related to motility. Its presence in only the ventral flagella of Giardia therefore provides a unique opportunity to elucidate the relationship between ciliary structure and function in the same organism.

The observed locations of the 4B8 target in tissues and cells of various origin, suggest a

35 similarity to annexins - and specifically to $\alpha$-19-giardin. This raises the possibility that it is involved in intra-flagellar transport and provides a basis for further studies aiming at its identification.

\section{Author Summary}

Pneumocystis is a ubiquitous fungal organism apparently colonizing the lung at an early age

40 to cause pneumonia only in individuals with an impaired immune system. In the alveolar spaces of such individuals, extensive and frequently fatal proliferation of the pathogen 
occurs. Pneumocystis has no known reservoir in nature and apparently is transmitted directly from infected individuals via an airborne route. Adaptation of this Ascomycotic fungus to a parasitic lifestyle during its evolution apparently resulted in dependence upon host nutrients,

45 but little is known about this presumed adaptation process. In this report, a previously unrecognized constituent of human Pneumocystis is detected using a monoclonal antiPneumocystis jiroveci antibody (Moab 4B8) which was obtained as a by-product in the search for reagents useful in diagnostics. The Moab 4B8 was shown to react with Pneumocystis but also with cytoskeletal microtubules, e.g. in ciliated epithelia, but not

50 ubiquitously a constituent of the conserved cilia/flagella axonemal structure. A striking example of the discriminating capacity of antibody 4B8 was seen in immunofluorescent staining of the protozoan Giardia intestinalis, where only one out of four flagellar pairs expresses the target epitope. This observation of flagellar heterogenicity provoked the question raised in the title of this report. It also provides the basis for the discussion, which

55 arrives at suggestive evidence for the involvement of the described evolutionarily conserved target in host-pathogen interactions related to membrane transport.

\section{Background}

At the onset of the aids epidemic we attempted to develop improved diagnostics of Pneumocystis pneumonia by generating monoclonal antibodies to Pneumocystis (1)(2).

60 Massive clusters of intra-alveolar Pneumocystis organisms causing often fatal pneumonia in infected lungs (3) was a re-emerging problem associated with immunosuppression as pneumocystis pneumonia was known to be fatal in malnourished children in post-war Europe.(4)(5) Cysts could be identified by the pathologist using silver stains such as the Grocott-Gomori silver precipitation stain commonly used to visualize fungi, but higher sensitivity could be achieved using monoclonal antibodies as immuno-cytological markers. 
(1)(2) With the recognition that Pneumocystis is a fungal organism and the identification of the host-specific human pathogen Pneumocystis jiroveci. (6), the cysts are regarded as asci of Ascomycete fungi and the "trophozoites" equivalent to vegetative yeast.

Monoclonal antibodies, such as 3F6, which were developed to improve the sensitivity of

70 diagnostics were shown to detect not only the cyst form, but also the trophozoites (1), which are the main constitutes of intra-alveolar clusters of organisms in pneumocystis pneumonia (7) (8). However, some of the anti-Pneumocystis monoclonal antibodies, like 4B8, obtained by immunization with a urea extract of Pneumocystis infected human lung tissue also reacted with controls such as cultured mammalian cells and tissues and therefore regarded as useless.

75 Especially the recently recognized fundamental importance of cilia, motivated an attempt to further explore the significance of the observed cross reaction of antibody 4B8 with the ventral flagella of Giardia intestinalis (9).

\section{Materials and Methods}

\section{Pneumocystis materials and generation of anti-Pneumocystis antibodies}

80 Crude extracts of Pneumocystis infected lung tissue, obtained at autopsy from a fatal case of Pneumocystis pneumonia (PCP) was prepared by homogenization in 8M urea, followed by centrifugation at $1000 \mathrm{~g}$. The supernatant, was used for immunization of CBA mice for the production of monoclonal antibodies (Moab) as described earlier (1).

Briefly, hybridoma culture supernatants were screened for antibody activity by two assays: An enzyme-immunoassay (ELISA) in which microtiter plates were coated with the $8 \mathrm{M}$ urea lung extract used for immunization (protein concentration of $10 \mathrm{ng} / \mathrm{ml}$.) Bound antibodies were detected with horseradish-peroxidase-(HRP) conjugated sheep 
anti mouse immunoglobulin conjugate followed by substrate/chromogen solution which was recorded with a Titer-Tec (Flow Laboratories) fotometer.

90 ELISA-reactive supernatants were then tested for reactivity by an indirect immunofluorescence (IFL) assay using paraffin sections of Pneumocystis infected lung tissue as antigen (see below).

Electron microscopy was performed on ultrathin sections of Pneumocystis-infected lung material using standard fixation and epon-embedding techniques essentially as described 95 before (10) (11)

ELISA and IFL-reactive hybridoma supernatants were tested by Western blotting after separation of the urea-soluble tissue material by polyacrylamide gel electrophoresis (PAGE) (12) and electrophoretic transfer of material on to nitrocellulose paper (13). The sheep anti-mouse HRP conjugate was used in concentration of $10 \mathrm{mg} / \mathrm{ml}$.

100 Molecular weight standards were: carbonic anhydrase 30, ovalbumin 43, albumin 67 $\mathrm{kDa}$, phosphorylase b $94 \mathrm{kDa}$. (Pharmacia, Sweden)

A two-cycled microtubule protein preparation of bovine brain (14) containing mainly alpha and beta tubulins (approximately 80\%), kindly provided by Margareta Wallin, University of Gothenburg, was used as reference in Western blotting experiments.

105 Cells, tissues and parasites used as antigens. Antibodies used in immunolocalization experiments.

Vero cells and Hela cells were cultured under standard conditions in RPMI 1640 medium containing $10 \%$ foetal calf serum glutamine, penicillin and streptomycin Flow Laboratories, Herts, England. Cells grown on glass coverslips or suspensions of cells were smeared as 
110 monolayers on microscope slides and fixed in cold acetone as described previously (15).For Giardia intestinalis WB isolate in axenic culture we used TYI-S-33 medium supplemented with bile. (16) Chlamydomonas reinhardi algae in Sueoka's medium (17) were provided by Susan Dutcher, Department of Genetics, Washington University School of Medicine, St. Louis, Missouri.

115 Vinblastine sulphate (Sigma Chemical Co, St Louis, Mo) was added to cell culture medium to disrupt the microtubules cytoskeleton (18)

Different life cycle stages of Schistosoma mansoni worms were obtained from parasite life cycle maintained in the laboratory as described previously (19). For immunohistology, human lung tissue, mouse tissues and Schistosoma mansoni worms were fixed in Bouin's

120 fixative (5\% acetic acid $9 \%$ formaldehyde, $0.9 \%$ picric acid) and embedded in paraffin for preparation of tissue sections for immunohistology as described previously (10). Monoclonal antibodies (Moab) 3F6, 4B8 and 2E3 against Pneumocystis were generated as described above (1). Moab 3F6 was also obtained from DAKO/Agilent CODE IR635 (https://www.agilent.com/cs/library/catalogs/public/00230_atlas_of_stains.pdf).

125 Monoclonal anti-tubulin antibodies 1A2, 3G6 and rabbit antibody antiTB ASP were from Thomas Kreis $\uparrow$ EMBL, Heidelberg (20).

Deparaffinized tissue sections and fixed cultured cells on microscope slides were incubated with hybridoma culture supernatant, to detect bound antibodies, a sheep anti-mouse immunoglobulin FITC conjugate (National Bacteriology Laboratory (NBL), Stockholm) was

130 used. Fluorescence microscopy was performed using a Zeiss standard microscope. Some microscope pictures from double stained tissue sections obtained on Kodak Tri-X black and white negative film were pseudo-colored using Adobe Photoshop CC 2019 graphics editor. Some of the immunohistology and TEM preparations containing Pneumocystis material was 
bioRxiv preprint doi: https://doi.org/10.1101/2020.05.09.085829; this version posted May 10, 2020. The copyright holder for this preprint (which was not certified by peer review) is the author/funder. All rights reserved. No reuse allowed without permission.

$$
\text { E. Linder Moab 4B8 anti Pneumocystis jiroveci }
$$

made available for virtual microscopy (21) at the Webmicroscope home page:

http://demo.webmicroscope.net/research/parasitology.

\section{Results}

The 4B8 antibody recognizes a Pneumocystis surface antigen cross reacting with a variety of tissues and organisms. Its distribution was similar or identical to that of reference anti-tubulin antibodies e.g in cultured cells. However, co-localization with tubulin was not absolute: The

140 most striking example was the selective localization of the epitope at the ventral but not the anterior, posterior-lateral or caudal flagellar pair of Giardia intestinalis.

Thus, the 4B8 target epitope, was not seen in all axonemal structures and co-localization with tubulin was not universal.

\section{Reaction of antibody 4B8 with Pneumocystis and cross-reactivity by indirect}

145 immunofluorescence with protozoa, algae and metazoa.

Lung tissue used for preparation of the material for immunization and generation of mouse monoclonal antibodies contained abundant Pneumocystis organisms, as seen in both light and electron micrographs. (Fig.1)

The antibody 4B8 stained Pneumocystis jiroveci cysts (asci) in intra-alveolar parasite clusters

150 similarly as the parasite-specific antibody 3F6. Clusters of Pneumocystis organisms can be distinguished in paraffin sections stained by indirect immunofluorescence (Fig 2) The abundance of intra-alveolar Pneumocystis organisms is evident in tissue sections, which can be examined by virtual microscopy and additional ultrastructural observations can be seen at http://demo.webmicroscope.net/research/parasitology. Reference anti-tubulin antibody

155 1A2 stained intra-cystic material but not the cyst wall. (Fig. 2) 
bioRxiv preprint doi: https://doi.org/10.1101/2020.05.09.085829; this version posted May 10, 2020. The copyright holder for this preprint (which was not certified by peer review) is the author/funder. All rights reserved. No reuse allowed without permission.

\section{E. Linder}

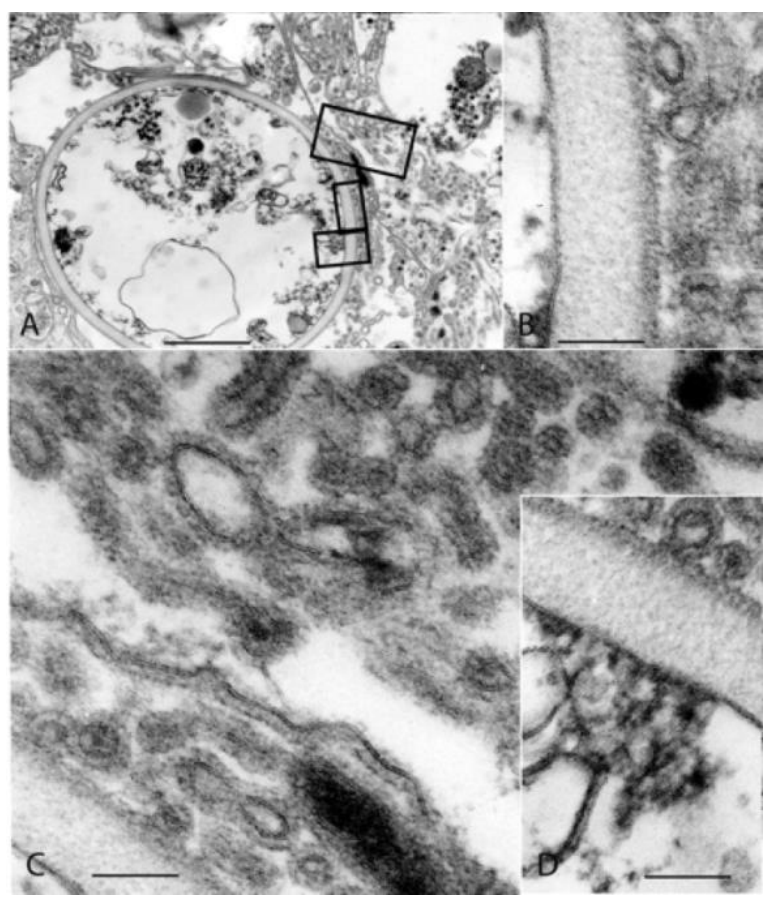

Fig. 1 Ultrastructural appearance of

Pneumocystis jiroveci organisms in lung tissue from fatal case of pneumocystis pneumonia used in this study for the generation of monoclonal antibodies. Cross section of an ascus (cyst) $(\boldsymbol{A})$. In inserts $(\boldsymbol{B}$, $C, D)$, three morphologically distinct structures are indicated: Intra-cystic trophic forms (tr), tubular extensions (tu) ("filopodia“), which are continuous with the outer electron dense layer of the wall of the ascus. Bar equals 1 micron.

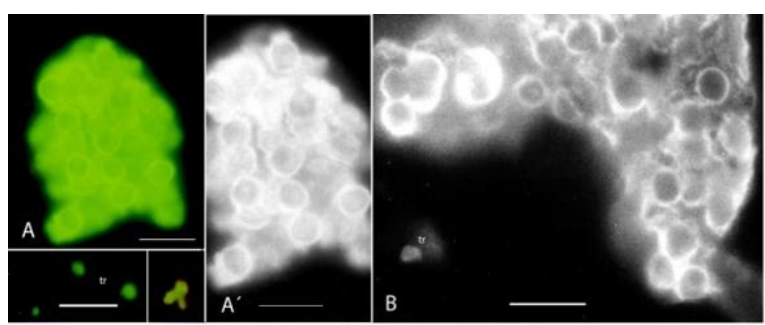

Fig. 2 In broncho-alveolar lavage samples from patient with pneumocystis pneumonia, clusters of Pneumocystis organisms are stained similarly by indirect immunofluorescence with monoclonal antibody 4B8 ( $\boldsymbol{A}$ and $\boldsymbol{A}^{\prime}$ ) and parasitespecific antibody3F6 $(\boldsymbol{B})$. Note staining of both cyst walls and material occupying the space between cysts. Both antibodies also react with trophozoites (tr). In paraffin sections of lung tissue, cyst walls of intraalveolar Pneumocystis clusters stain distinctly with 4B8 $(\boldsymbol{C})$ whereas anti-tubulin antibody $1 \mathrm{~A} 2$ gave a lumpy or coarse granular reaction pattern, but no staining of cvst walls $(\boldsymbol{D})$. Bar eauals 15 microns.

By immunoblotting, antibody 4B8 reacted with 3 components, 82, 60 and $45 \mathrm{kDa}$

components present in the Pneumocystis extract whereas reference antibody 3F6 like reacted

160 with only one $82 \mathrm{kDa}$ component. In Giardia preparations, a 45-50 kDa component was seen.

4B8 reacted with a component slightly smaller than the tubulin band recognized by Moab

$1 \mathrm{~A} 2$ in the bovine brain tubulin preparation. (Fig. 3) 
bioRxiv preprint doi: https://doi.org/10.1101/2020.05.09.085829; this version posted May 10, 2020. The copyright holder for this preprint (which was not certified by peer review) is the author/funder. All rights reserved. No reuse allowed without permission.

E. Linder

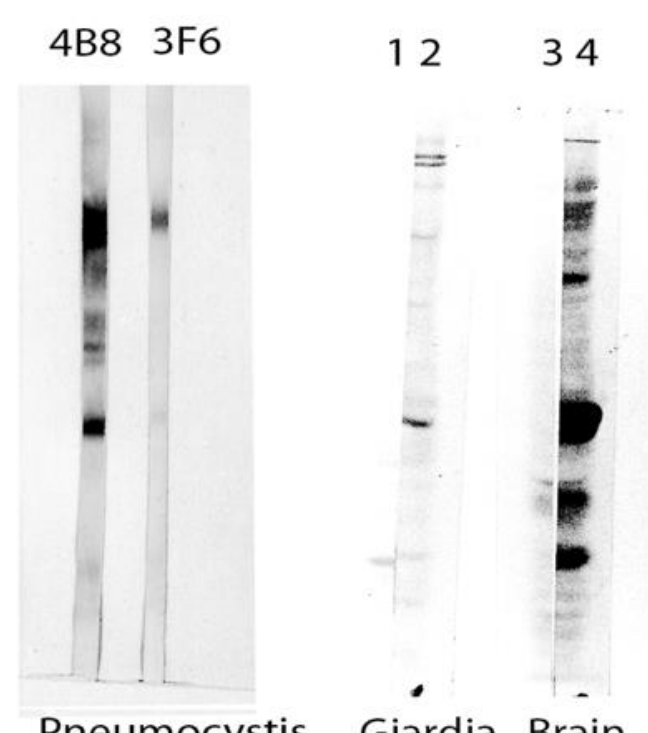

Moab 4B8 anti Pneumocystis jiroveci

Fig. 3 Immunoblotting using monoclonal antibodies 4B8 and control Pneumocystisspecific antibody 4B8 on nitrocellulose paper transfer of Pneumocystis-infected lung tissue urea-extract after one-dimensional polyacrylamide gel electrophoresis. Reactivity of 4B8 with major Pneumocystis components of about $80 \mathrm{kDa}$ and $45 \mathrm{kDa}$. 3F6 reacts with compoinent of about $80 \mathrm{kDa}$. Reactivity of Giardia and rat brain with antibody 4B8. Control strips (lanes 1 and 3) are buffer controls not incubated with monoclonal antibody. Reactions with bovine brain tubulin in amounts from 1.5 to $20 \mathrm{ug}$. Antibody 4B8 reacts with a component (lanes 1-5) which is slightly smaller than the component reacting with anti-tubulin antibody 1 A2 (lanes 6-10). Size markers: Phosphorylase B $(94 \mathrm{kDa})$; human serum albumin $(67 \mathrm{kDa})$; bovine serum albumin $(43 \mathrm{kDa})$ and carbonic anhydrase $(30 \mathrm{kDa})$.

By indirect immunofluorescence staining, antibody 4B8 reacts with some but not all flagella.

This was seen as reactivity with some but not all flagellated organisms. The flagella of

Chlamydomonas reacted (Fig. 4), whereas Trypanosoma cruzi and Leishmnania tropica

flagella did not (Fig 5). 
bioRxiv preprint doi: https://doi.org/10.1101/2020.05.09.085829; this version posted May 10, 2020. The copyright holder for this preprint (which was not certified by peer review) is the author/funder. All rights reserved. No reuse allowed without permission.

E. Linder

Moab 4B8 anti Pneumocystis jiroveci
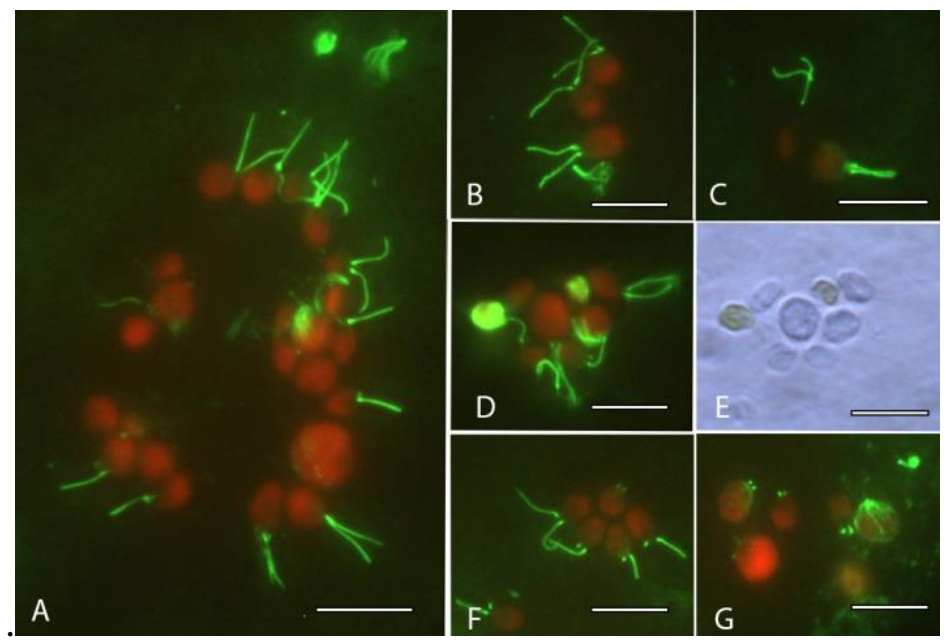

Fig. 4 Reactivity of monoclonal antibody 4B8 with Chlamydomonas reinhardti flagellar pair and basal bodies. Note staining of the basal bodies also in organisms which have lost one or both flagella during the staining procedure. $(\mathrm{A}, \mathrm{F}$ and $G$ ) Redistribution of the 4B8 target antigen during cell division is seen in $\mathrm{G}$ and $\mathrm{D} / \mathrm{E}$. Bars equal 10 microns

The flagella of these protozoa, however, showed reaction with anti-tubulin antibodies (Fig $5 \mathrm{C})$.

Reactive and non-reactive flagella were present in the same organism, Giardia intestinalis.

The Giardia ventral flagellar pair reacted, but not the 3 other bilaterally symmetrical pairs,

180 the anterior, posterior-lateral and caudal ones (Fig. 5). In some dividing cells, intracytoplasmic fine granular strands were seen (Fig 5Ba)

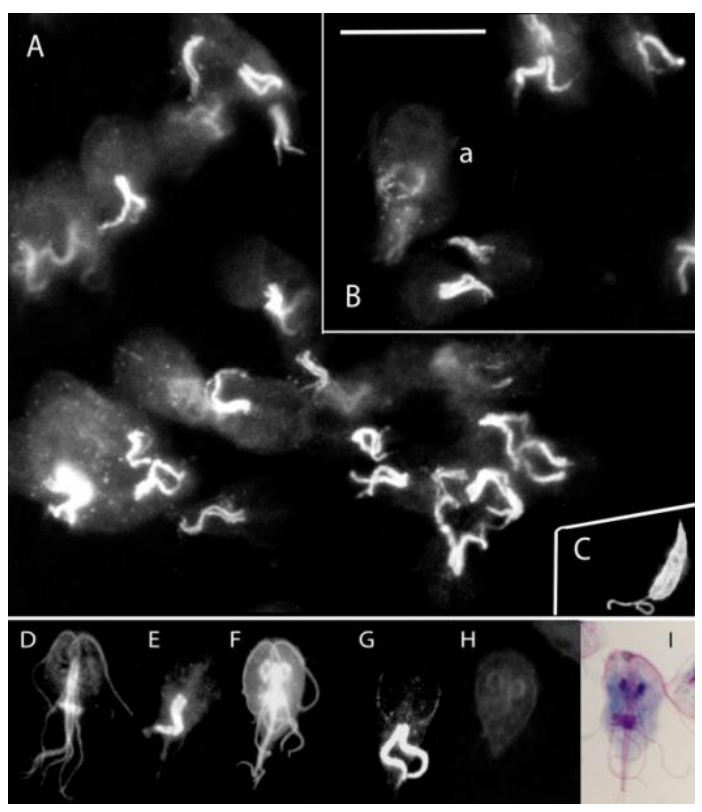

Fig. 5 Reactivity of monoclonal antibody 4B8 with Giardia intestinalis $(\boldsymbol{A}, \boldsymbol{B}, \boldsymbol{E}$ and $\boldsymbol{G})$. Anti-tubulin antibody $1 \mathrm{~A} 2$ with. $4 \mathrm{~B} 8$ reacts only with the ventral flagellar pair. Antitubulin reference antibody reacts with all Giardia flagella and in Leishmnania tropica epimastigotes both the flagellum and the cell membrane $(\boldsymbol{C})$ Monoclonal anti-tubulin antibodies 1A2 $(\boldsymbol{D})$ and 3B6 $(\boldsymbol{F})$ react with all flagella and the median body. Rabbit antibody antiTB ASP shows weak perinuclear reaction. (H) Bar equals 10 microns

Antibody 4B8 appeared not to stain the intracytoplasmic part located of the posteriorly directed ventral flagella. Control staining with anti-tubulin antibodies showed reactivity with 
bioRxiv preprint doi: https://doi.org/10.1101/2020.05.09.085829; this version posted May 10, 2020. The copyright holder for this preprint (which was not certified by peer review) is the author/funder. All rights reserved. No reuse allowed without permission.

$$
\text { E. Linder Moab 4B8 anti Pneumocystis jiroveci }
$$

In the metazoan parasitic worm Schistosoma mansoni, antibody 4B8 reacted with three distinct cell types; the ciliated surface epithelium of miracidia, flame cells and the nervous system. (Fig. 6).

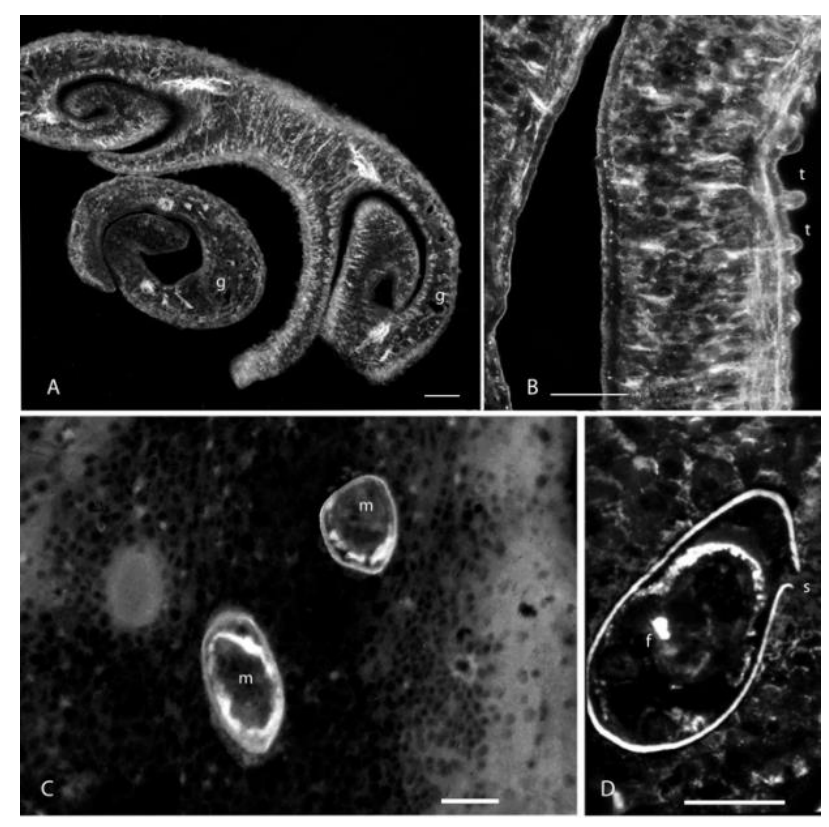

Fig. 6 Reactivity of monoclonal antibody 4B8 with Schistosoma mansoni adult worm pair. (A), Schistosoma mansoni male worm $(\boldsymbol{B})$ shows localization in the longitudinal nerve bundles and in subtegumental nerve fibers. The ciliated surface $(\mathrm{m})$ and flame cell (f) of intraoval miracidia $(\boldsymbol{C})$ and $(\boldsymbol{D})$. Bars equal 50 microns

190 In cultured fibroblasts and HeLa cells the 4B8 TA co-localized with tubulin and was present in the mitotic spindle. In cell cultures treated with the microtubulus-disrupting drug Vinblastine, the 4B8 TA was seen in cytoplasmic paracrystals (Fig. 7),

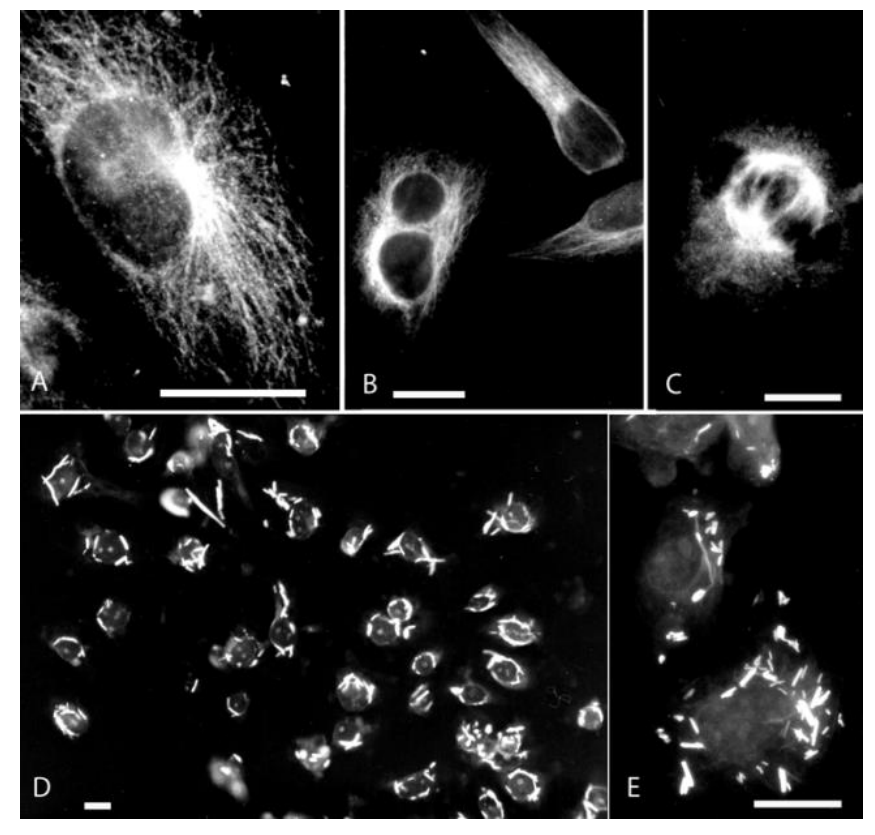

Fig. 7 Reactivity of monoclonal antibody 4B8 with cultured Vero cells $(A)$. Similar staining pattern is seen with anti-tubulin $1 \mathrm{~A} 2(\boldsymbol{B})$. Staining using antibody $4 \mathrm{~B} 8$ of the mitotic spindle $(\boldsymbol{C})$ and staining of paracrystals in cells in after addition of microtubule-disrupting drug Vinblastine to the culture medium $(\boldsymbol{D}$, E).

Bars equal 5 microns. 
bioRxiv preprint doi: https://doi.org/10.1101/2020.05.09.085829; this version posted May 10, 2020. The copyright holder for this preprint (which was not certified by peer review) is the author/funder. All rights reserved. No reuse allowed without permission.

$$
\text { E. Linder Moab 4B8 anti Pneumocystis jiroveci }
$$

195 Reaction of antibody $4 \mathbf{B 8}$ with tissues. In rat tissues (Fig. 8), Moab 4B8 reacted with ciliated epithelia in several tissues studied, e.g. bronchial epithelium, Fallopian tubes and ependymal cells. The 4B8 TA was seen in both central and peripheral nervous system. In some cells without cilia such as cells in the central nervo (Fig. 8E) and in Purkinje cells of the cerebellum (Fig. 8I

200 granular.

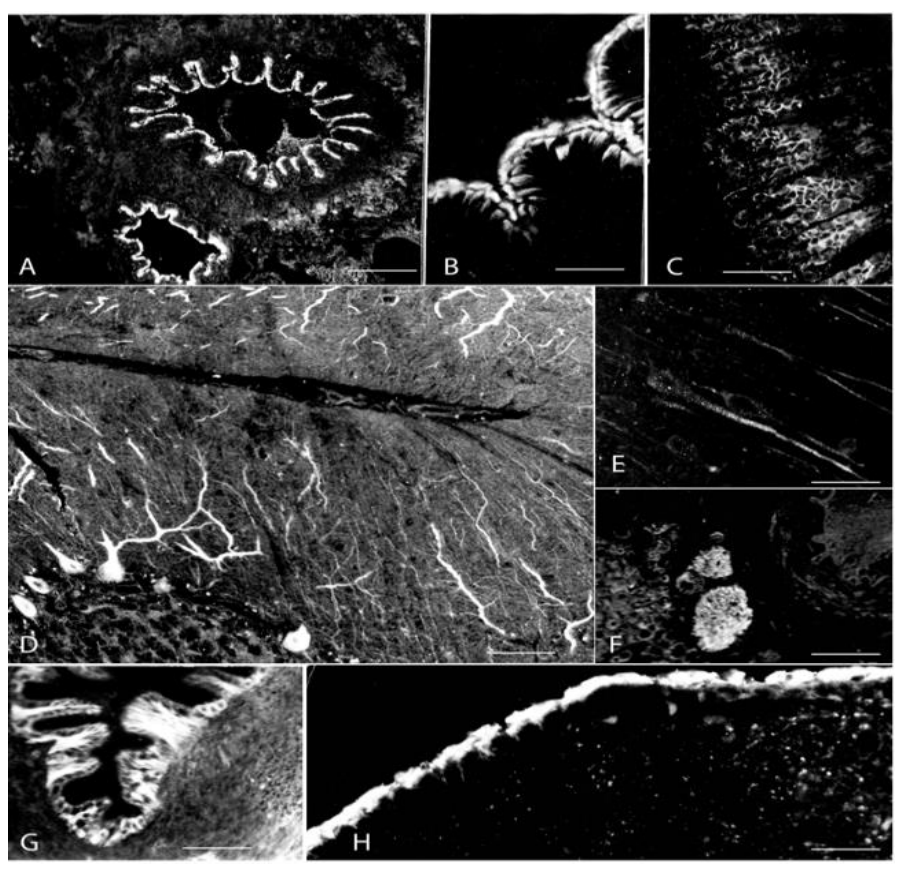

Fig. 8 Reactivity of monoclonal antibody 4B8 with mouse tissues. Epithelium of bronchus $(\boldsymbol{A})$ and oesophagus $(\boldsymbol{B})$. Gastric epithelium $(\boldsymbol{C})$. Purkinje cells of the cerebellum $(\boldsymbol{D})$. Nerve cells in the cerebral cortex- note the fine granular staining pattern $(\boldsymbol{E})$. Peripheral nerves $(\boldsymbol{F})$. Fallopian tubes $(\boldsymbol{G})$. Ependymal cells $(\boldsymbol{H})$. Bars equal 40 microns

The 4B8 target antigen was present in the seminiferous tubes of the testis in Sertoli cells and developing spermatocytes (Fig. 9).

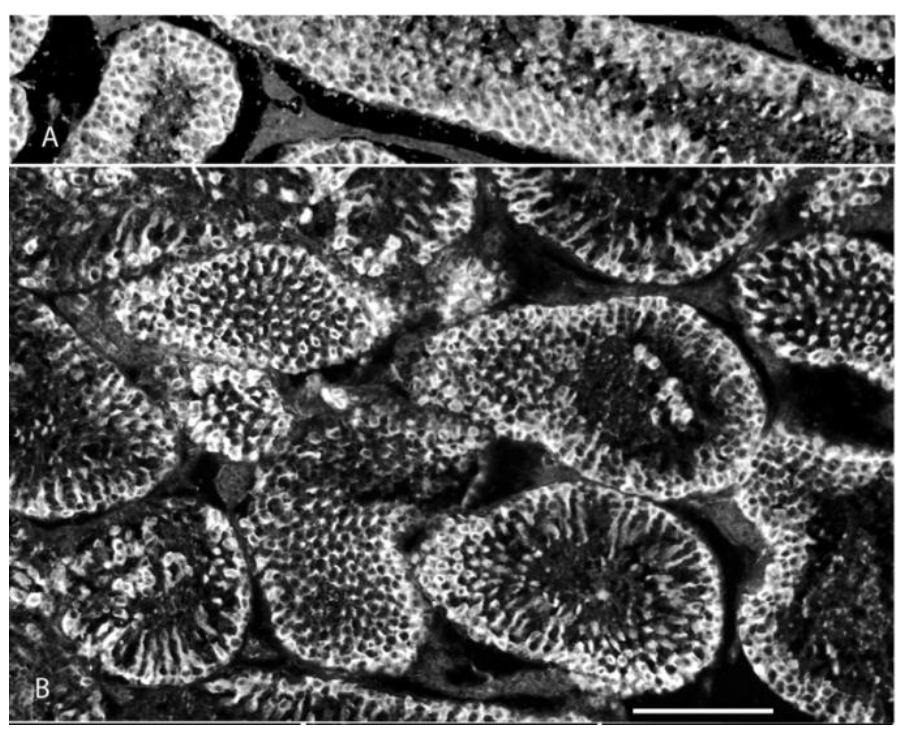

Fig. 9 Reactivity of monoclonal antibody 4B8 with rat testis. Seminiferous tubes are seen in longitudinal $(\boldsymbol{A})$ and transverse sections $(\boldsymbol{B})$. Both developing spermatocytes and Sertoli cells react, whereas interstilial areas containing Leydig cells do not. Bar equals 150 microns. 
bioRxiv preprint doi: https://doi.org/10.1101/2020.05.09.085829; this version posted May 10, 2020. The copyright holder for this preprint (which was not certified by peer review) is the author/funder. All rights reserved. No reuse allowed without permission.

\section{E. Linder}

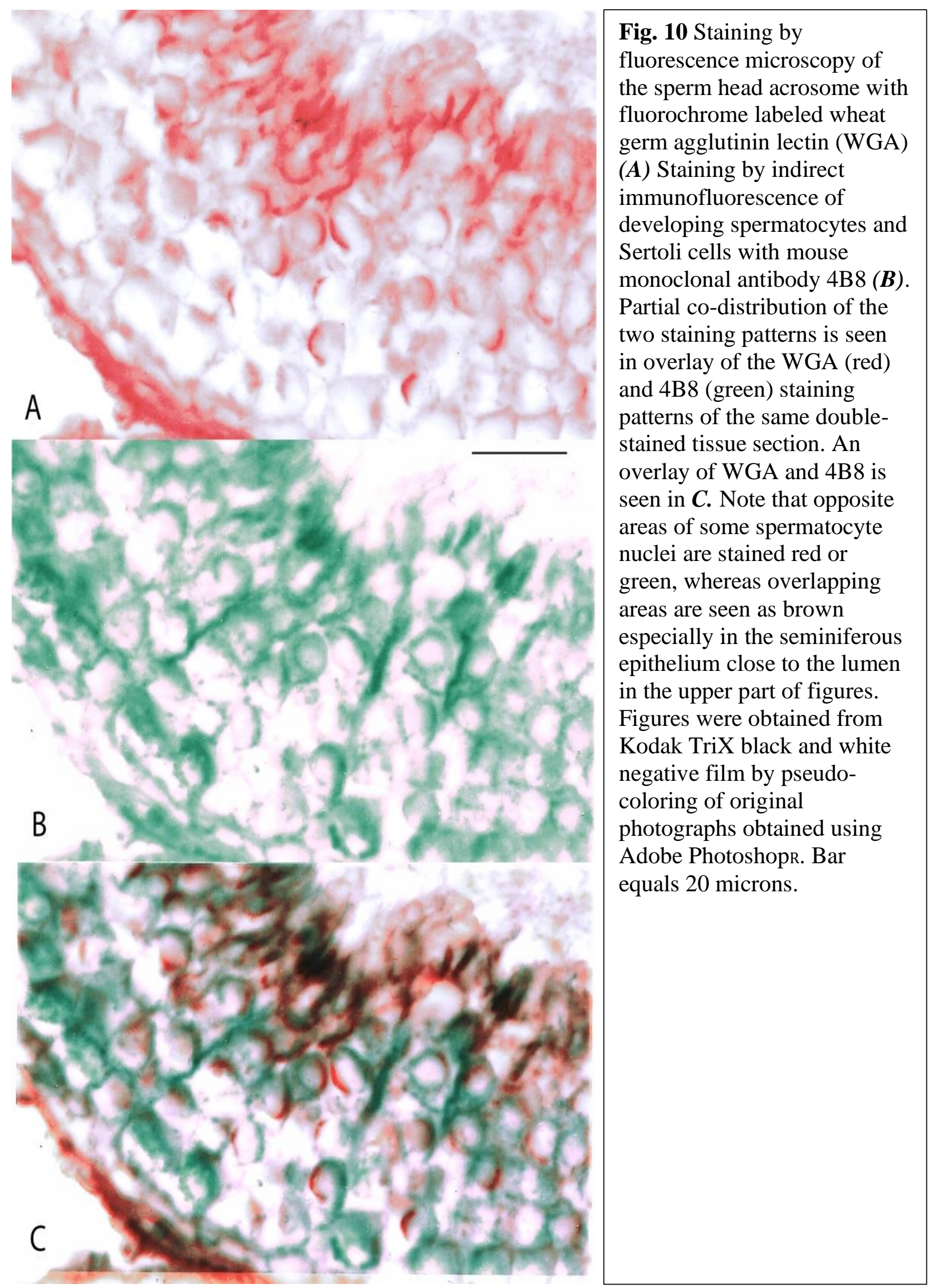


Table 1 Reactivity of mouse monoclonal antibodies* with various targets in indirect immunofluorescence staining.

$\begin{array}{lllll}\text { Targets } & 4 \mathrm{B8} \dagger & 3 \mathrm{~F} 6 \div & 1 \mathrm{~A} 2 & \begin{array}{l}\text { Figure } \\ \text { no. }\end{array}\end{array}$

\begin{tabular}{|c|c|c|c|c|}
\hline \multicolumn{5}{|l|}{ Pathogens ${ }^{\S}$ and cultured cells } \\
\hline Pneumocystis jiroveci & + & + & $+* *$ & 1,2 \\
\hline Giardia intestinalis & $+\dagger$ & - & + & 5 \\
\hline Plasmodium falciparum & - & - & + & - \\
\hline Trypanosoma gambiense & - & - & + & - \\
\hline Trypanosoma cruzi & - & - & + & - \\
\hline Leishmania tropica & - & - & + & 5 \\
\hline Schistosoma mansoni & + & - & + & 6 \\
\hline Chlamydomonas reinhardti & + & - & + & 4 \\
\hline Crithidia luciliae & - & - & + & - \\
\hline Spironucleus salmonicida & + & - & & - \\
\hline HeLaş & + & - & + & 7 \\
\hline Vero**** & + & - & + & 7 \\
\hline \multicolumn{5}{|l|}{ Rat tissues ${ }^{++t}$} \\
\hline Airway epithelium $+*$ & + & - & + & 8 \\
\hline Fallopian tube epithelium & + & - & + & 8 \\
\hline Ependymal cells of brain ventricles & + & - & + & 8 \\
\hline Purkinje cells in cerebellum & + & - & + & 8 \\
\hline Peripheral nerves & + & - & + & 8 \\
\hline Oesophagus & + & - & + & 8 \\
\hline Testis, seminiferous tubes & + & - & + & 9,10 \\
\hline
\end{tabular}

* Anti- Pneumocystis monoclonal antibodies (Moab) 4B8 and 3F6 (1). Antibody 1A2 reacts with tubulin (20)

${ }^{+}$Anti- Pneumocystis Moab 4G3 reacted like 4B8.

‡ Anti- Pneumocystis Moab 2E3 reacted like 3F6.

$\S$ Pathogens available as they were used as antigen for the detection of specific antibodies in patient sera.

${ }^{* *}$ No reaction with cyst wall

${ }^{++} 4 \mathrm{~B} 8$ staind only ventral flagella. 1A2 reacts with all 4 flagellar pairs.

¥¥ Only stages present in peripheral blood of infected patient were tested. Sexual stages were not tested

$\S \S$ HeLa cell line derived from cervical cancer

*** Fibroblast-like Vero cell line isolated from an African green monkey kidney.

${ }^{++}$Tissues were not systematically studied but selected primarily for their content of ciliated epithelia.

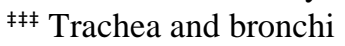




\section{Discussion}

The surprising finding, that antibody 4B8 generated by immunization of mice with Pneumocystis jiroveci cross-reacts with cilia and is capable of distinguishing the ventral flagella of Giardia from the other flagella of this organism, provoked the question "what's so special about the Giardia ventral flagella?" In trying to answer this question, an attempt is

215 made to shed some light on host-pathogen interactions in Pneumocystis infection. Antibody 4B8, and the pneumocystis-specific antibody 3F6, reacted with intra-alveolar clusters of Pneumocystis organisms similarly. In such clusters, three main morphologically distinguishable structures are seen; asci, trophozoites and filopodia. The asci are easily recognized in light microscopy e.g after staining with silver stains (6)(22), but the vegetative stage, trophozoites, measuring a few $\mu \mathrm{m}$ in diameter and constituting $90-95 \%$ of the total parasite population in the lungs of infected hosts (23), are difficult to recognize in light microscopy without specific markers. $(2)(24)(25)(26)(8)(21)(27)$ The third morphologically distinct morphological feature, tubular projections similar to filopodia or microvilli (28), can barely be recognized by conventional light microscopy (29), but surface projections (Fig 1) are seen as clusters hundreds of small tubules in ultrathin sections in both human and rat Pneumocystis in transmission electron microscopy. (30)(31)(32)(33)(34) The Pneumocystisspecific antibody 3F6 recognizes localized such tubular extensions in addition to both cysts and trophozoites. (35) Filopodia have been linked to nutrition of the organism (28)(29)(36), a function further suggested by the observation that filopodia are surrounded by tissue exudate, not by air. (29)(26)

Anti-tubulin antibody reacted with Pneumocystis trophozoites (Fig 2), which is consistent with the reported localization of tubulin in trophozoites at the ultrastructural level (37). Antitubulin antibodies stained clusters of organisms occupying the alveolar spaces in Pneumocystis pneumonia (Fig 2), but not the cyst wall, which is consistent with the 
235 ultrastructural observation by Bedrossian, who observed no microtubules in the cyst wall or tubular extensions. (38)

\section{Localization of the anti-4B8 target epitope in association with microtubules.}

Localization of the 4B8 target epitope was observed both at the tissue and the cellular level in association with cytoskeletal microtubules. This was evident from immunostaining both in

240 cultured cells and in ciliated epithelia. The cytoskeletal microtubular network of cultured cells is easily recognized. Cilia/flagella, of e.g. Chlamydomonas algae have the common internal arrangement of 9+2 microtubule doublets, which constitute the conserved axonemal structure (39).

However, the 4B8 target epitope is not present in this basic axonemal structure as it is absent

245 from some axonemes, such as flagella of Trypanosomes and interestingly lacking in 3 out of 4 flagellar pairs of Giardia. Interestingly all the axonemes if Giardia flagella appear to be similar: Reorganization of the flagellar apparatus in dividing Giardia involves flagellar transformation: "... a maturation process during which the flagella migrate, assume different position and transform to different flagellar types in progeny..." (40). This transformation

250 through which the respective axonemes change their position takes place by reorientation and migration of the pairs of basal bodies. During the transformation process the flagellar function is altered as parent anterolateral flagella become caudal and both parent posterolateral and ventral flagella become anterolateral in daughter cells. The similarity of Giardia flagellar axonemes is consistent with the fact that no member of the tubulin family or 255 post-translational tubulin modification is associated selectively with the Giardia ventral flagella. (see supplementary information in S1) 
bioRxiv preprint doi: https://doi.org/10.1101/2020.05.09.085829; this version posted May 10, 2020. The copyright holder for this preprint (which was not certified by peer review) is the author/funder. All rights reserved. No reuse allowed without permission.

$$
\text { E. Linder Moab 4B8 anti Pneumocystis jiroveci }
$$

A
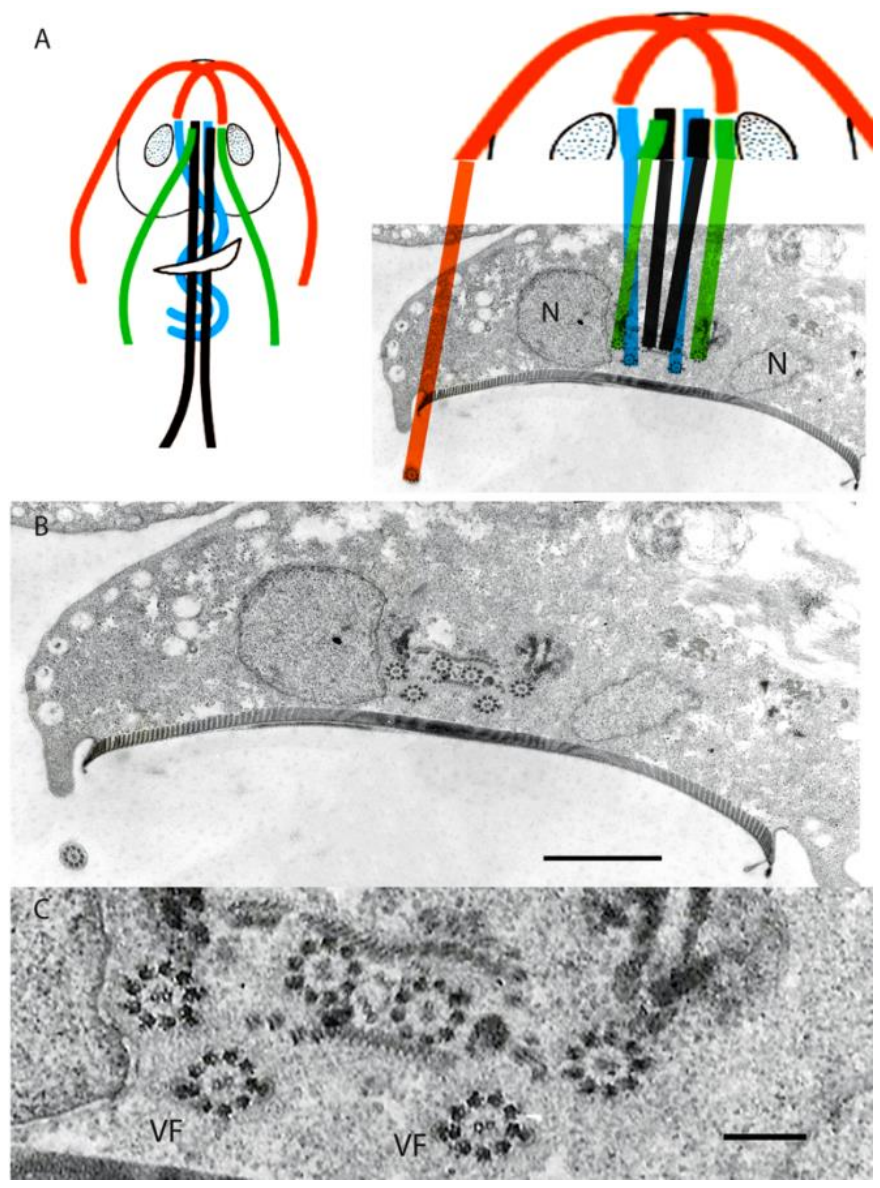

Fig. 11 Transmission electron micrograph of Giardia trophozoite showing cross section of the four flagellar pairs running at the level of the caudal portion of the nuclei as indicated in the schematic drawing (A) (modified from (40)). Ventral flagella axonemes (blue and VF) are associated with two lateral electron dense masses. Antero-lateral flagella (red), postero-lateral flagella (green) and caudal flagella (black). Size bars $1 \mathrm{micron}$ in $\boldsymbol{B}$ and $200 \mathrm{~nm}$ in $\boldsymbol{C}$.

The anti-4B8 staining of the ventral Giardia flagella appeared to be located periphery of the axoneme proper and did not appear to stain the intracytoplasmic portion of the axoneme (see

Fig 5). The pattern of staining of the Giardia ventral flagella was fine granular and appeared to be localized closer to the plasma membrane than the axoneme stained by anti-tubulin antibody $1 \mathrm{~A} 2$.

Giardia species has been shown to contain numerous vesicular structures apparently forming a complex endomembrane system of protein sorting and transport which evolved early in eukaryotes (41)., Para-axial electron dense ancillary structures beneath the membrane that run alongside the axoneme from its point of emergence to the flagellar tip (corresponding to those seen in VF in Fig 11), and present only in association with the ventral flagellar axonemes have been demonstrated previously. (42)(43) These functionally uncharacterized paired paraflagellar structures characteristic of ventral flagella are dissolved after detergent 
treatment to produce pure axonemes for transmission electron microscopy.

$(44)(45)(46)(47)(48)$

Recent genomic and proteomic approaches have identified novel flagellar proteins and advanced our understanding of fundamental aspects of eukaryotic flagellum structure and function.(49). The number of components associated with the microtubules of the conserved $9+2$ axonemal structure is surprisingly high, and their functional significance is only beginning to unfold.(39)(50)(51) In Giardia more than 300 microtubulus-associated proteins are thought to occur (52). The apparent localization of the 4B8 target in association with some axonemes is interesting as the axoneme has been shown to recruit distinct protein components to confer functional differences to cilia at distinct locations, e.g. mucus-

280 propelling cilia in the trachea and water-propelling cilia in brain ventricles (53).

The subsequent discussion will consider to what extent the localization of the 4B8 target antigen is consistent with a conserved function such as intra-flagellar transport (IFT) (54).

\section{Localization in tissues.}

The 4B8 target epitope was seen in ependymal cells lining the brain ventricles and in Sertoli cells of the epididymis, two distinct tissues which share the functional characteristics of being part of the blood-tissue barrier. Ependymal cells lining of the brain are a type of glia cells which form a continuous sheet lining the ventricles, choroid plexuses and the central canal of the spinal cord. They have a simple columnar shape and are ciliated much like mucosal epithelia. Ependymal cells have a cerebrospinal fluid-brain barrier function and participate in the control of water transport and ion homeostasis.

In the seminiferous tubules of the testes microtubules are abundant in apical regions of Sertoli cells, and are closely related to ectoplasmic specializations attached to the adjacent spermatid heads. There is a close contact between Sertoli cells and mature germ cells (spermatids). Just prior to spermiation, the elongated spermatid interacts with the Sertoli cell 
295 via an extensive structure comprising various adhesion molecules called apical tubulobulbar complexes. (55)(56)(57)(58) Microtubule-based transport appears to occur both in the manchette and at intercellular adhesion junctions in the Sertoli cell plasma membrane. The cytoskeleton of Sertoli cells and the manchette of developing spermatocytes are known to contain abundant networks of microtubules. Structural proteins are apparently delivered to

300 the basal body through intra-manchette transport and required for correct formation of the sperm tail and acrosome and shaping of the head. (59).

Cells of the central and peripheral nervous system react with antibody 4B8 both in the flatworm Schistosoma and in the rat. The parasitic schistosome worm belongs to the most primitive metazoan phylum, Platyhelminthes. The worm neuron is highly secretory and contains a heterogeneity of vesicular inclusions, dominated by vesicles, whose contents may be released synaptically or by paracrine secretion for presumed delivery to target cells via the extracellular matrix. (60)(61)

In the rat cerebellum, staining of large neurons located as a single layer between the outer molecular layer and the inner granular layer. These Purkinje cells are sole output neurons of

310 the cerebellar cortex bridging motor and non-motor domains. Both peripheral and central nervous tissues are involved in vesicle transport and signal processing. Axonal transport of different cargos depends on an incompletely known set of molecules along intracellular tracks formed by the microtubule networks.(62)

The internalization of components of the plasma membrane-associated ligands and fluid is a

315 fundamental process in eukaryotic cells and molecules involved in cliliary functions have apparently been present in a common ancestor about one billion years ago (63) Membrane transport is involved in diverse processes such as uptake of nutrients and intercellular signaling. Clathrin-mediated endocytosis is an essential cellular mechanism by which eukaryotic cells regulate their plasma membrane composition to control cell signaling, 
320 adhesion, migration and morphogenesis.(64) Attachment of Pneumocystis trophozoites to lung epithelium triggers proliferation and life cycle progression. (22) Interestingly, results of genome analysis show preservation in Pneumocystis of nearly all proteins associated with clathrin-dependent endocytosis. (32) Wether membrane transport occurs through the vast surface area provided by Pneumocystis tubular extensions or filopodia needs to be shown, but

325 a plausible working hypothesis is that Pneumocystis filopodia are involved in uptake of nutrients provided by the host. Such a function is consistent with the observed location of the anti-4B8 target antigen in Chlamydomonas flagella and the Giardia ventral flagella, which are known to be involved in flagellar functions unrelated to the flagellar beat. The region between the flagellar plasma membrane and the outer tubulins of the axoneme is a

330 highly complex structure where trains of particles located closely to the inner surface of the flagellar membrane bridge to each other and to the outer doublet microtubules. (65)(42)(66)(67) Intraflagellar transport (IFT) of cargoes takes place along the length of the flagella along microtubules and the components of IFT and their assembling in the flagella seem to be highly conserved during evolution and their encoding genes also exist in the

335 Giardia genome. (65)(68)(69)(70)

A closer look into the protein components of the Giardia cytoskeleton shows that it contains mainly giardins in addition to tubulins. (71) The multi-gene giardin family has 21 members (72), which are associated with Giardia flagella differently (73); The $\alpha-13$ giardin is a cytoplasmic protein (74), the $\alpha 18$-giardin localized at all flagella (74), and the $\alpha-11$ giardin is

340 mainly localized to the plasma membranes and basal bodies of the anterior flagella (75). A striking observation is that $\boldsymbol{\alpha}$-19-giardin is found only in the Giardia ventral flagella (76): Polyclonal antibodies raised against a recombinant $\alpha$-19-giardin protein reacted in a Western blot assay with a protein of about $47 \mathrm{kDa}$ in the pellet fraction of a Giardia trophozoite extract. (76) Thus, both the localization of the 4B8 target epitope to the ventral flagella and 


\section{E. Linder}

345 its molecular mass of about 50kDa raises the possibility, that antibody 4B8 recognizes $\alpha-19-$ giardin.

The $\alpha$-giardins are recognized as annexin homologues based on sequence similarities and in the novel nomenclature, Giardia annexins have been given the designation, annexin E. Annexins are $\mathrm{Ca} 2+$ and membrane binding proteins forming an evolutionary conserved

350 multigene family comprising >500 different gene products expressed throughout animal and plant kingdoms. Many of the group E annexins interact with different cytoskeletal structures or the membrane. Annexins are involved in numerous cell processes including vesicle trafficking, calcium signaling, cell growth, division, and apoptosis (77)(78). Annexin A13b is known to interact with other proteins and helps to direct them to their destination points. In

355 epithelial cells, this annexin is suggested to play a role in the formation of transport vesicles and their fusion with the apical membrane (79). It is conceivable that annexins exist in Pneumocystis as they are found in most medically important fungal pathogens. (80) (81) A final point for discussion is the evidence for an immune response selectively against Giardia ventral flagellar antigens and their possible involvement in infection immunity. Interestingly detergent soluble molecules selectively localizing to the ventral flagella appear to be immunogenic and to induce a humoral immune response in both human and murine Giardia infections. (43) Wether protective immunity against Giardia infection mediated by mothers milk (82) involves antibodies against the Giardia ventral flagella - and the 4B8 target antigen - is not known. However, preliminary results (83)(84) showed that $42 \%$ (25 out of

365 59) of mothers milk samples from a giardiasis-endemic region, contain antibodies reacting selectively with Giardia ventral flagella. This was twice the prevalence of antibodies reacting with all Giardia flagella in this material. 


\section{E. Linder}

Thus, the results of this study suggest that looking for more answers to the question "What's so special about Giardia ventral flagella?" may reveal novel aspects of host-pathogen interactions.

\section{Acknowledgements}

Several persons have kindly contributed over the years to the experiments resulting in this report and the results could not have been obtained without their generous help. To name the most important contributors, Cecilia Thors $\uparrow$ performed much of the laboratory work together with Jadwiga Winiecka-Krusnell who managed to rescue monoclonal antibodies through the turmoil of institutional re-organizations. Protozoa and helminth materials were obtained from the diagnostics laboratory of the Parasitology Department of the Swedish National Bacterilology Laboratory (SBL). Carl-Henrik von Bonsdorff performed the electron microscopy. Thomas Kreis $\uparrow$ provided anti-tubulin antibodies and Margareta Wallien the

380 bovine brain tubulin preparation. The Chlamydomonas culture was a gift from Susan Dutcher and the Spironucleus specimens were from Staffan Svärd.

Johan and Mikael Lundin arranged for supplementary image material to be accessible at the Webmicroscope.net website. My former students Seppo Meri and Antti Sukura are thanked for encouragement.

\section{References}

1. Linder E, Lundin L, Vorma H. Detection of Pneumocystis carinii in lung-derived samples using monoclonal antibodies to an $82 \mathrm{kDa}$ parasite component. J Immunol Methods. 1987;98(1):57-62.

390 2. Linder E, Elvin K, Bjorkman A, Bergdahl S, Morfeldt-Mansson L, Moberg L, et al. 
Monoclonal antibody to detect pneumocystis carinii. Lancet. 1986;2(8507):634.

3. Raab SS, Cheville JC, Bottles K, Cohen MB. Utility of Gomori methenamine silver stains in bronchoalveolar lavage specimens. Mod Pathol. 1994 Jun;7(5):599-604.

4. van der Meer M, Brug S. Infection à Pneumocystis chez l'homme et chez les animaux. Ann Soc Belg Med Trop. 1942;22:301-9.

5. Vanek J. Atypicka (interstitiálni) pneumonie detí vyvolaná Pneumocystis carinii (atypical interstitial pneumonia of infants produced by Pneumocystis carinii). Casop lék Ces. 1951;90:1121-4.

6. Chabé M, Aliouat-Denis C-M, Delhaes L, Aliouat EM, Viscogliosi E, Dei-Cas E. Pneumocystis: from a doubtful unique entity to a group of highly diversified fungal species. FEMS Yeast Res. 2011;11(1):2-17.

7. Aliouat-Denis C-MM, Martinez A, Aliouat EM, Pottier M, Gantois N, Dei-Cas E. The pneumocystis life cycle. Mem Inst Oswaldo Cruz. 2009;104(3):419-26.

8. Elvin KM, Bjorkman A, Linder E, Heurlin N, Hjerpe A. Pneumocystis carinii pneumonia: Detection of parasites in sputum and bronchoalveolar lavage fluid by monoclonal antibodies. Br Med J. 1988;297(6645):381-4.

9. Linder E. Monoclonal antibody to Pneumocystis detects microtubulus-associated antigens in mammalian cells and Giardia. In: Maccioni RB, Aréchaga Martínez J, editors. The Cytoskeleton in cell differentiation and development : proceedings of the first international symposium, Granada, Spain, April 21-25, 1987 IRL press. 367 pages. Oxford [England] ; Washington, DC: Published for the ICSU Press by IRL Press, (C1987.; 1987. p. 179-82.

10. Linder E, Thors C. Schistosoma mansoni: Praziquantel-induced tegumental lesion exposes actin or surface spines and allows binding of actin depolymerizing factor, 
415 gelsolin. Parasitology. 1992;105(1):71-9.

11. Sukura A, Ukkola T, Linder E, Lindberg L-AA. Ultrastructural localization of monoclonal antibodies against Pneumocystis carinii. Differentiation between developmental stage and host origin. APMIS. 1994;102(12):901-7.

12. Laemmli UK, Favre M. Maturation of the head of bacteriophage T4. I. DNA packaging events. J Mol Biol. 1973;80, 575,

13. Towbin H, Staehelin T, Gordon J. Electrophoretic transfer of proteins from polyacrylamide gels to nitrocellulose sheets: Procedure and some applications. Proc Natl Acad Sci U S A. 1979;76,4350-4354

14. Miller HP, Wilson L. Preparation of microtubule protein and purified tubulin from bovine brain by cycles of assembly and disassembly and phosphocellulose chromatography. Vol. 95, Methods in Cell Biology. Academic Press Inc.; 2010. 2-15 p.

15. Kurki P, Virtanen I, Stenman S, Linder E. Characterization of human smooth muscle autoantibodies reacting with cytoplasmic intermediate filaments. Clin Immunol Immunopathol. 1978;11(4):379-87.

16. Smith PD, Gillin FD, Spira WM, Nash TE. Chronic Giardiasis: Studies on Drug Sensitivity, Toxin Production, and Host Immune Response. Gastroenterology. 1982 Oct 1;83(4):797-803.

17. Salomé PA, Merchant SS. A series of fortunate events: Introducing chlamydomonas as a reference organism. Vol. 31, Plant Cell. American Society of Plant Biologists; 2019. p. $1682-707$.

18. Bensch KG, Malawista SE. Microtubule crystals: A new biophysical phenomenon induced by Vinca alkaloids. Vol. 218, Nature. 1968. p. 1176-7. 
bioRxiv preprint doi: https://doi.org/10.1101/2020.05.09.085829; this version posted May 10, 2020. The copyright holder for this preprint (which was not certified by peer review) is the author/funder. All rights reserved. No reuse allowed without permission.

E. Linder

Moab 4B8 anti Pneumocystis jiroveci

19. Thors C. Serodiagnostics of schistosomiasis using keyhole limpet hemocyanin (KLH) as antigen [Internet]. Thesis from Microbiology and Tumor Biology Center Karolinska Institutet, Stockholm, Sweden. Karolinska Institutet, Stockholm, Sweden; 2006. Available from: https://openarchive.ki.se/xmlui/handle/10616/40167

20. Kreis TE. Microtubules containing detyrosinated tubulin are less dynamic. EMBO J. 1987 Sep;6(9):2597-606.

445 21. Linder E, Lundin M, Thors C, Lebbad M, Winiecka-Krusnell J, Helin H, et al. Webbased virtual microscopy for parasitology: a novel tool for education and quality assurance. PLoS Negl Trop Dis. 2008;2(10):e315.'

22. Skalski JH, Kottom TJ, Limper AH. Pathobiology of Pneumocystis pneumonia: life cycle, cell wall and cell signal transduction. Munro C, editor. FEMS Yeast Res. 2011;15(6):fov046.

23. Martinez A, Aliouat EM, Pottier M, Gantois N, Pinçon C, Standaert-Vitse A, et al. High-speed cell sorting of infectious trophic and cystic forms of Pneumocystis carinii. J Eukaryot Microbiol. 1997;56(5):446-53.

24. Elvin K, Linder E. Application and staining patterns of commercial anti-Pneumocystis carinii monoclonal antibodies. J Clin Microbiol. 1993;31(8):2222-4.

25. Lautenschlager I, Lyytikainen O, Jokipii L, Jokipii A, Maiche A, Ruutu T, et al. Immunodetection of Pneumocystis carinii in bronchoalveolar lavage specimens compared with methenamine silver stain. J Clin Microbiol. 1996;34:728-730.

26. Ma L, Cissé OH, Kovacs JA. A Molecular Window into the Biology and Epidemiology of Pneumocystis spp. Clin Microbiol Rev. 2018;31(3):e00009-18.

27. MoMic Slides [Internet]. [cited 2020 Jan 12]. Available from: http://fimm.webmicroscope.net/Research/Momic/momic 
28. Murphy MJ, Pifer LL, Hughes WT. Pneumocystis carinii in vitro: A study by scanning electron microscopy. Am J Pathol. 197;86(2):387-401.

29. Shiota T, Yamada M, Yoshida Y. Morphology, development and behavior of

Pneumocystis carinii observed by light-microscopy in nude mice. Zentralbl Bakteriol Mikrobiol Hyg A. 1986;262(2):230-9.

30. De Souza W, Benchimol M. Basic biology of Pneumocystis carinii: a mini review. Mem Inst Oswaldo Cruz. 2005 Dec;100(8):903-8.

31. Vavra J, Kuncera K. Pneumocystis carinii Delanoë, its Ultrastructure and Ultrastructural Affinities. J Protozool. 1970;17(3):463-83.

32. Millard PR, Wakefield AE, Hopkin JM. A sequential ultrastructural study of rat lungs infected with Pneumocystis carinii to investigate the appearances of the organism, its relationships and its effects on pneumocytes. Int J Exp Pathol. 1990 ;71(6):895-904.

475 33. Nielsen MH, Settnes OP. Morphology of Pneumocystis carinii and activation of the plasmalemmal vesicular system in alveolar epithelial cells of the host. An ultrastructural study. APMIS. 1991;99(3):219-25.

34. Nielsen MH, Settnes OP, Aliouat EM, Cailliez JC, Dei-Cas E. Different ultrastructural morphology of Pneumocystis carinii derived from mice, rats, and rabbits. APMIS. 1998 Aug [cited 2015 Oct 27];106(8):771-9.

35. Sukura A, Ukkola T, Linder E, Lindberg LA. Ultrastructural-Localization Of Monoclonal-Antibodies Against Pneumocystis-Carinii - Differentiation Between Developmental Stage And Host Origin. APMIS. 1994;102(12):901-7.

36. Yoshida Y, Matsumoto Y, Yamada M, Okabayashi K, Yoshikawa H, Nakazawa M. trophozoite and alveolar lining cell. Zentralbl Bakteriol Mikrobiol Hyg A. 
1984;256(3):390-9.

37. Yu JR, Pyon JK, Seo M, Jung BS, Cho SR, Lee SH, et al. Localization of cytoskeletal proteins in Pneumocystis carinii by immuno-electron microscopy. Korean J Parasitol. 2001;39(1):13-21.

38. Bedrossian CW. Ultrastructure of Pneumocystis carinii: a review of internal and surface characteristics. Semin Diagn Pathol. 1989;6(3):212-37.

39. Lindemann CB, Lesich KA. Flagellar and ciliary beating: The proven and the possible. Vol. 123, Journal of Cell Science. 2010. p. 519-28.

40. Nohýnková E, Tůmová P, Kulda J. Cell division of Giardia intestinalis: Flagellar developmental cycle involves transformation and exchange of flagella between mastigonts of a diplomonad cell. Eukaryot Cell. 2006 Apr;5(4):753-61.

41. Gillin FD, Reiner DS, McCaffery JM. Cell biology of the primitive eucaryote Giardia lamblia. Annu Rev Microbiol. 1996;50(1):679-705.

42. Elmendorf HG, Dawson SC, Mccaffery JM. The cytoskeleton of Giardia lamblia. Int J Parasitol. 2003;33(1):3-28.

43. Clark JT, Holberton D V. Triton-labile antigens in flagella isolated from Giardia lamblia. Parasitol Res. 1988 Sep;74(5):415-23.

44. Crossley R, Holberton D V. Characterization of proteins from the cytoskeleton of Giardia lamblia. J Cell Sci. 1983;59:81-103.

45. Crossley R, Marshall J, Clark JTT, Holberton DV V. Immunocytochemical differentiation of microtubules in the cytoskeleton of Giardia lamblia using monoclonal antibodies to alpha-tubulin and polyclonal antibodies to associated low molecular weight proteins. J Cell Sci. 1986;80(1):233-52. 
bioRxiv preprint doi: https://doi.org/10.1101/2020.05.09.085829; this version posted May 10, 2020. The copyright holder for this preprint (which was not certified by peer review) is the author/funder. All rights reserved. No reuse allowed without permission.

E. Linder

Moab 4B8 anti Pneumocystis jiroveci

510 46. Dawson SC. An insider's guide to the microtubule cytoskeleton of Giardia. Cell Microbiol. 2010;12(5):588-98.

47. House SA, Richter DJ, Pham JK, Dawson SC. Giardia Flagellar Motility Is Not Directly Required to Maintain Attachment to Surfaces. Sibley LD, editor. PLoS Pathog. 2011;7(8):e1002167.

515 48. Lenaghan SC, Davis CA, Henson WR, Zhang Z, Zhang M. High-speed microscopic imaging of flagella motility and swimming in Giardia lamblia trophozoites. Proc Natl Acad Sci U S A. 2011;108(34):E550-8.

49. Ralston KS, Kabututu ZP, Melehani JH, Oberholzer M, Hill KL. The Trypanosoma brucei flagellum: moving parasites in new directions. Annu Rev Microbiol. 2009;63:335-62.

50. Ostrowski LE, Dutcher SK, Lo CW. Cilia and Models for Studying Structure and Function. Proc Am Thorac Soc. 2011;8:423-429.

51. Pazour GJ, Agrin N, Leszyk J, Witman GB. Proteomic analysis of a eukaryotic cilium. J Cell Biol. 2005;170(1):103-13.

525 52. Hagen KD, McInally SG, Hilton ND, Dawson SC. Microtubule organelles in Giardia. In: Advances in Parasitology. Academic Press; 2020.

53. Konno A, Shiba K, Cai C, Inaba K. Branchial Cilia and Sperm Flagella Recruit Distinct Axonemal Components. PLoS One. 2015;10(5):e0126005.

54. Satir P. CILIA: before and after. Cilia. 2017;6:1.

530 55. Felekis D, Vogler H, Mecja G, Muntwyler S, Nestorova A, Huang T, et al. Real-time automated characterization of 3D morphology and mechanics of developing plant cells. Int J Rob Res. 2015;34(8):1136-46. 
56. Wong CH, Cheng CY. The Blood-Testis Barrier: Its Biology, Regulation, and Physiological Role in Spermatogenesis. Current Topics in Developmental Biology. $2005 ; 71,263-96$.

57. Guttman J, Kimel G, AW Vogl -. Dynein and plus-end microtubule-dependent motors are associated with specialized Sertoli cell junction plaques (ectoplasmic specializations) [Internet]. Journal of cellScience. 2000 [cited 2020 Feb 29]. Available from: https://jcs.biologists.org/content/113/12/2167.short

540 58. Upadhyay RD, Kumar A V., Ganeshan M, Balasinor NH. Tubulobulbar complex: cytoskeletal remodeling to release spermatozoa. Vol., Reproductive biology and endocrinology : RB\&E. BioMed Central 2012;10: 27.

59. Lehti MS, Sironen A. Formation and function of the manchette and flagellum during spermatogenesis. Reproduction. 2016 Apr 1;151(4):43-54.

545 60. Gustafsson MKS. Immunocytochemical demonstration of neuropeptides and serotonin in the nervous system of adult Schistosoma mansoni. Parasitol Res. 1987 Mar;74(2):168-74.

61. Halton DW, Gustafsson MKS. Functional morphology of the platyhelminth nervous system. Parasitology. 1996 Jan;113(S1):S47-72.

550 62. Bodakuntla S, Jijumon AS, Villablanca C, Gonzalez-Billault C, Janke C. MicrotubuleAssociated Proteins: Structuring the Cytoskeleton. Trends Cell Biol. 2019 Oct 1;29(10):804-19.

63. Mitchell DR. Evolution of Cilia. Cold Spring Harb Perspect Biol. 2017 Jan $3 ; 9(\mathrm{a} 028290)$.

555 64. Haucke V, Kozlov MM. Membrane remodeling in clathrin-mediated endocytosis. Vol. 131, Journal of Cell Science. Company of Biologists Ltd; 2018. 
bioRxiv preprint doi: https://doi.org/10.1101/2020.05.09.085829; this version posted May 10, 2020. The copyright holder for this preprint (which was not certified by peer review) is the author/funder. All rights reserved. No reuse allowed without permission.

$$
\text { E. Linder }
$$

65. Kozminski KG, Johnson KA, Forscher P, Rosenbaum JL. A motility in the eukaryotic flagellum unrelated to flagellar beating. Proc Natl Acad Sci U S A. 1993;90(12):5519_ 23.

560 66. Pigino G, Geimer S, Lanzavecchia S, Paccagnini E, Cantele F, Diener DR, et al. Electron-tomographic analysis of intraflagellar transport particle trains in situ. J Cell Biol. 2009 Oct 5;187(1):135-48.

67. Pigino G, Bui KH, Maheshwari A, Lupetti P, Diener D, Ishikawa T. Cryoelectron tomography of radial spokes in cilia and flagella. J Cell Biol. 2011;195(4):673-87.

565 68. Prevo B, Scholey JM, Peterman EJG. Intraflagellar transport: mechanisms of motor action, cooperation, and cargo delivery. Vol. 284, FEBS Journal. Blackwell Publishing Ltd; 2017. p. 2905-31.

69. Lafont F, Lecat S, Verkade P, Simons K. Annexin XIIIb associates with lipid microdomains to function in apical delivery. J Cell Biol. 1998 Sep 21;142(6):1413-27.

70. Simons K, Ikonen E. Functional rafts in cell membranes. Nature. 1997;387:569-72.

71. Morgan RO, Fernandez MP. Molecular phylogeny of annexins and identification of a primitive homologue in Giardia lamblia. Mol Biol Evol. 1995;12(6):967-979.

72. Weiland MEL, McArthur AG, Morrison HG, Sogin ML, Svärd SG. Annexin-like alpha giardins: A new cytoskeletal gene family in Giardia lamblia. Int J Parasitol. $2005 ; 35(6): 617-26$.

73. Vahrmann A, Šarić M, Koebsch I, Scholze H. $\alpha 14$-Giardin (annexin E1) is associated with tubulin in trophozoites of Giardia lamblia and forms local slubs in the flagella. Parasitol Res. 2008;102(2):321-6.

74. Wu S, Pan W, Shi X, Abdullahi AY, Wang Z, Yu X, et al. Immunolocalization of $\alpha 18$ - 
and $\alpha 12$-giardin in Giardia lamblia trophozoites. Parasitol Res. 2016 Nov

$$
1 ; 115(11): 4183-7 .
$$

75. Wei CJ, Tian XF, Adam RD, Lu SQ. Giardia lamblia: Intracellular localization of alpha8-giardin. Exp Parasitol. 2010 Dec;126(4):489-96.

76. Šarić M, Vahrmann A, Niebur D, Kluempers V, Hehl AB, Scholze H, et al. Dual acylation accounts for the localization of $\alpha 19$-giardin in the ventral flagellum pair of giardia lambliaV. Eukaryot Cell. 2009 Oct;8(10):1567-74.

77. Gerke V, Moss SE. Annexins: From structure to function. Physiological Reviews. 2002.

78. Rescher U, Gerke V. Annexins - Unique membrane binding proteins with diverse functions. J Cell Sci. 2004 Jun 1;117(13):2631-9.

79. Turnay J, Lecona E, Fernández-Lizarbe S, Guzmán-Aránguez A, Fernández MP, Olmo $\mathrm{N}$, et al. Structure-function relationship in annexin A13, the founder member of the vertebrate family of annexins. Biochem J. 2005 Aug 1;389(3):899-911.

80. Khalaj K, Aminollahi E, Bordbar A, Khalaj V. Fungal annexins: a mini review. SpringerPlus. 2015.

81. Maryam M, Fu MS, Alanio A, Camacho E, Diego G, Faneuff EE, et al. The enigmatic role of fungal annexins: The case of cryptococcus neoformans. Microbiol (United Kingdom). 2019;165(8).

82. Tellez A, Winiecka-Krusnell J, Paniagua M, Linder E. Antibodies in mother's milk protect children against giardiasis. Scand J Infect Dis. 2003;35(5):322-5.

83. Téllez Sierra A. Giardiasis in Leon, Nicaragua [Internet]. Karolinska InstitutetDepartment of Microbiology, Tumor and Cell Biology; 2006 [cited 2020 Feb 
bioRxiv preprint doi: https://doi.org/10.1101/2020.05.09.085829; this version posted May 10, 2020. The copyright holder for this preprint (which was not certified by peer review) is the author/funder. All rights reserved. No reuse allowed without permission.

$$
\text { E. Linder }
$$

17]. Available from: https://openarchive.ki.se/xmlui/handle/10616/43570

84. Tellez A, Palm D, Weiland M, Aleman J, Winiecka-Krusnell J, Linder E, et al. Secretory antibodies against Giardia intestinalis in lactating Nicaraguan women. Parasite Immunol. 2005;27(5):163-9.

85. Nohýnková E, Dráber P, Reischig J, Kulda J. Localization of gamma-tubulin in interphase and mitotic cells of a unicellular eukaryote, Giardia intestinalis. Eur J Cell Biol. 2000 Jun 1;79(6):438-45.

610 86. Weber K, Schneider A, Westermann S, Müller N, Plessmann U. Posttranslational modifications of $\alpha$ - and $\beta$-tubulin in Giardia lamblia, an ancient eukaryote. FEBS Lett. 1997;419(1):87-91.

87. Tellez A, Winiecka-Krusnell J, Palm D, Linder E. Antibodies in Nicaraguan mother's milk against Giardia intestinalis ventral flagella. Manuscr. 2006;

615 88. Sloboda RD, Belfi LM. Purification of tubulin and microtubule-associated proteins by membrane ion-exchange chromatography. Protein Expr Purif. 1998;13(2):205-9.

89. Wickstead B, Gull K. The evolution of the cytoskeleton. Vol. 194, Journal of Cell Biology. The Rockefeller University Press; 2011. p. 513-25.

90. Vaughan S, Attwood T, Navarro M, Scott V, McKean P, Gull K. New tubulins in protozoal parasites. Vol. 10, Current Biology. Current Biology Ltd; 2000. p. R258-9.

91. McKean PG, Vaughan S, Gull K. The extended tubulin superfamily. J Cell Sci . 2001;114(Pt 15):2723-33.

92. Dutcher SK. Long-lost relatives reappear: identification of new members of the tubulin superfamily. Curr Opin Microbiol. 2003;6(6):634-40.

625 93. Téllez Sierra A, Universitetsservice US), Tellez A. Giardiasis in Leon, Nicaragua : 
Prevalence and protection [Internet]. Karolinska InstitutetDepartment of Microbiology, Tumor and Cell Biology; 2006 [cited 2020 Feb 17]. Available from:

https://openarchive.ki.se/xmlui/handle/10616/43570

94. Loveland KL, Hayes TM, Meinhardt a, Zlatic KS, Parvinen M, de Kretser DM, et al. Microtubule-associated protein-2 in the rat testis: a novel site of expression. Biol Reprod. 1996 Apr 1;54(4):896-904. 


\section{S1 Discussion on Giardia tubulins}

635 As essential components of the eukaryotic cytoskeleton, microtubules fulfill a variety of functions that can be temporally and spatially controlled by tubulin posttranslational modifications. (63)(85)(86) The observation that the 4B8 target antigen has a molecular size similar to beta tubulin and a localization in the microtubular cytoskeleton suggested that the it may be a novel tubulin isoform with a mobility similar to beta tubulin (87). However, no

640 tubulin isoform or posttranslational modification associated only with ventral flagella is known. The axonemes of ventral flagella are involved in "... a maturation process during which the flagella migrate, assume different position and transform to different flagellar types in progeny..." (40). This transformation is mediated by reorientation and migration of the pairs of basal bodies through which the respective flagella change their position and function.

645 During the transformation process the parent anterolateral flagella become caudal, whereas both parent posterolateral and ventral flagella become anterolateral in daughter cells. This similarity of Giardia flagella is consistent with the fact that no member of the tubulin family or post-translational tubulin modification is associated selectively with the Giardia ventral flagella Despite the immunolocalization of antibody 4B8 to microtubules in cultured cells and cilia/flagella and reaction with a component of about 50kDa in western blotting, the 4B8 target epitope does not seem to be any known tubulin. Its presence in semi-purified preparation of bovine brain tubulin suggested initially that the antigen epitope was related to beta tubulin. However, by preparing purified tubulin from bovine brain by cycles of assembly and disassembly, the preparation contains microtubule-associated proteins(88). The target could be some specific epitope related to post-translational tubulin modification or a member of the tubulin family other than the tubulins assembled into 9+2 protofilaments of the microtubule wall (89). However, no reported tubulin (classes $\gamma, \delta, \varepsilon, \eta, \zeta$ and $\imath$ ) exhibit a 
bioRxiv preprint doi: https://doi.org/10.1101/2020.05.09.085829; this version posted May 10, 2020. The copyright holder for this preprint (which was not certified by peer review) is the author/funder. All rights reserved. No reuse allowed without permission.

E. Linder

selective reactivity with Giardia ventral flagella like the one observed with antibody 4B8 $(44)(45)(90)(91)(92)$. Also no selective reactivity with ventral flagella was reported in studies

660 on a panel of 23 monoclonal antibodies against different epitopes on $\mathrm{N}$ and $\mathrm{C}$ termini of alpha- and beta-tubulins and against known posttranslational modifications of tubulin.(40) This was confirmed in our experiments using a number of antibodies against tubulin-related antigens(93): These antibodies (from Sigma, St. Louis, USA) include mouse monoclonal antibodies reacting with alpha tubulin (clone B-5-1-2); anti-beta tubulin (clone tub 2.1); anti665 delta tubulin (antibody T3950 clone DTU-64) anti-epsilon tubulin (antibody T1323 clone TUB-11); anti-gamma tubulin (antibody T6557 clone GTU-88); anti-acetylated tubulin antibody (T6793 clone 6-11B-1); anti-polyglutamylated tubulin antibody (T9822 clone B3) and the polyclonal antibody to bovine brain microtubulus-associated proteins recognizing MAP2 and to a lesser extent tau (94). 